\title{
Pinguicula Vulgaris L. In The Champagne state of France: LIFE IN AN ALKALINE BOG
}

Laurent Legendre and Thomas Cieslak - University Jean Monnet of Saint Etienne • Laboratory of Plant Biotechnology applied to aromatic and medicinal herbs $\bullet 23$ rue du Dr Paul Michelon•42023 Saint Etienne Cedex 2• France laurent.legendre@univ-st-etienne.fr

Keywords: field studies: France, Pinguicula vulgaris.

\section{Abstract}

Pinguicula vulgaris was observed growing in the Champagne state of France near the city of Rheims during 1994-2000. The plants are the remnants of what was, up to the beginning of the 20th century, a largely distributed set of populations that grew all over the Champagne and Paris basins. During the time of the study, the three populations were living in alkaline bogs and were gradually reducing in size. The plants differed from most other $P$. vulgaris by their ability to generate large numbers of gemmae in the winter, the round shape of their seed capsules and the small size of their leaf rosettes. A rough description of their habitat is presented in this article to explain their survival and observed dwindling numbers.

\section{Introduction}

Pinguicula vulgaris L. has the largest distribution of all Pinguicula species. This range covers Greenland, Iceland, most of the northern half of Northern America and a large part of Western Europe from the far north, southwards to the Oural mountains and the Mediterranean sea (Figure 1). Pinguicula vulgaris thrives at elevations from sea level up to 2,200 $\mathrm{m}$ altitude (Casper 1966). This large geographical and elevational distribution contrasts with those of most other Pinguicula species that are generally found at few small isolated locations. The impressive adaptability is paralleled by a large variation in morphological traits (Casper 1966). Since the original description of $P$. vulgaris by Linneus in 1753, many subspecies, forms and varieties have been described. Casper (1966) lists 24 different taxa at subspecific or lower rank. However, comprehensive biometric measurements and comparative studies that could support infra-specific

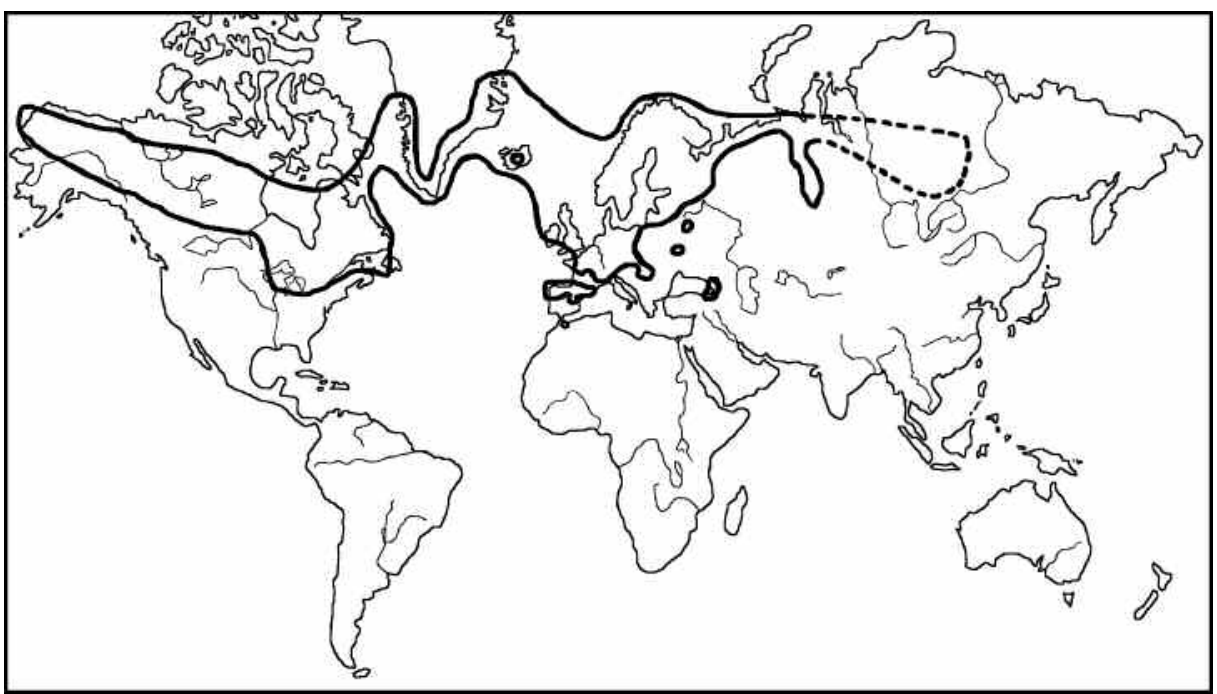

Figure 1: World distribution of $P$. vulgaris. 
splits are missing so that only two flower color variants ( $P$. vulgaris f. bicolor (Nordst. Ex Fries) Neumann and P. vulgaris f. albida (Behm) Neumann) were retained by Casper (1966) in his monographic revision of the genus. Steiger (1998) later described $P$. vulgaris var. transsilvanica Krajina, a variety with wider, often slightly overlapping corolla lobes and deeper separation of the lower calyx lobes. Pinguicula vulgaris grows in diverse biotopes. These include calcareous cliffs, acidic substrates (for example, a substratum $\mathrm{pH}$ of 4.9 has been determined for Greenland populations; Casper 1966) and gypsum-based substrates at $\mathrm{pH}$ values ranging from 5.7 to 8.2 for a west-pyrennee (southern France) population (Casper 1966).

Pinguicula vulgaris was observed 1994-2000 growing at three distinct sites in the Champagne state of France, all near the city of Rheims (Reims in French), $150 \mathrm{~km}$ east of the capital city, Paris. We could not confirm its presence on other sites previously described in this state. These three sites are less than $20 \mathrm{~km}$ apart and currently host 10, 100, and 2,000 plants. Even though these sites are at the center of the world distribution of $P$. vulgaris, the plants are isolated from their peers, the nearest populations of $P$. vulgaris being found more than $350 \mathrm{~km}$ away in the Netherlands, the Indre et Loire state of France or in distant mountain massifs of France, vosges, jura, alps or central massif (Dupont 1990). In the Champagne state of France, the plants are growing in a rarely described habitat, the alkaline bog. This article aims to relate some observations made on these plants and their biotope.

\section{Materials and Methods}

Seeds from the three populations (Chenay, Neuf-ans, Berru) growing in the Champagne state near the city of Rheims were collected in 1994 and 1995. Seeds of P. vulgaris were also collected over this same period from populations in the French vosges (Lac des truites), jura (City of Joux) and alps (Mont Joly). The exact provenances of the seeds of the Icelandic and Slovenian plants used in this study are unknown. Mature plants of $P$. vulgaris from Michigan (USA) were a gift of Pr. J.F. Steiger.

All seeds were germinated and grown at the center of the city of Rheims, in the same container $\left(65 \times 18 \times 22 \mathrm{~cm}^{3}\right)$ placed on a windowsill facing north-west. The community tank was equipped with a drainage hole $4 \mathrm{~cm}$ below the soil surface. Watering was done by the rain or, if this was insufficient to keep the water level up to the one of the drainage hole, tap water was added. The potting mix contained peat moss ( 5 parts), coarse sand ( 2 parts), local ground chalk (1 part), oak leaf litter (1 part) and oasis foam $\left(1 \mathrm{~cm}^{3}\right.$ cubes; 1 part). The potting mix was renewed once every other year early in the spring. Plants were grown and analyzed from 1994 till 2000.

Whole anthers were detached from mature flowers with tweezers and fixed by immersion in $5 \%$ glutaraldehyde followed by $2 \%$ osmium tetroxide. Fixed anthers were then critical point dried and glued on a scanning electron microscopy stub with high vacuum wax. The samples were sputter coated with platinum and viewed on an Hitachi S-800 SEM. Pollen grains present at the anther dehiscence hole were photographed. Their exudates were not washed prior to analysis. Mature, freshly harvested seeds were treated in a similar fashion.

\section{Results}

The flowers of the $P$. vulgaris plants of the three Champagne populations were similar in shape (Figure 2; Table 1) and differed slightly in color by being more pinkish-purple westward and more bluish-purple eastward. Their shape and color were consistent and within the range of variation currently accepted for $P$. vulgaris. Mature rosettes produced 1 or 2 flowers per season in the wild and when grown in Rheims, unlike the non-Champagne specimens in our study which produced an average of 4 to 10 flowers per season (Table 1). However, specimens in other cultural conditions in a western suburb of Paris have produced up to five flowers per season (E. Partrat, personal communication).

The rosettes of mature plants from the three studied Champagne populations were found to exhibit no significant difference in size in habitat and under cultivation. The Champagne plants 

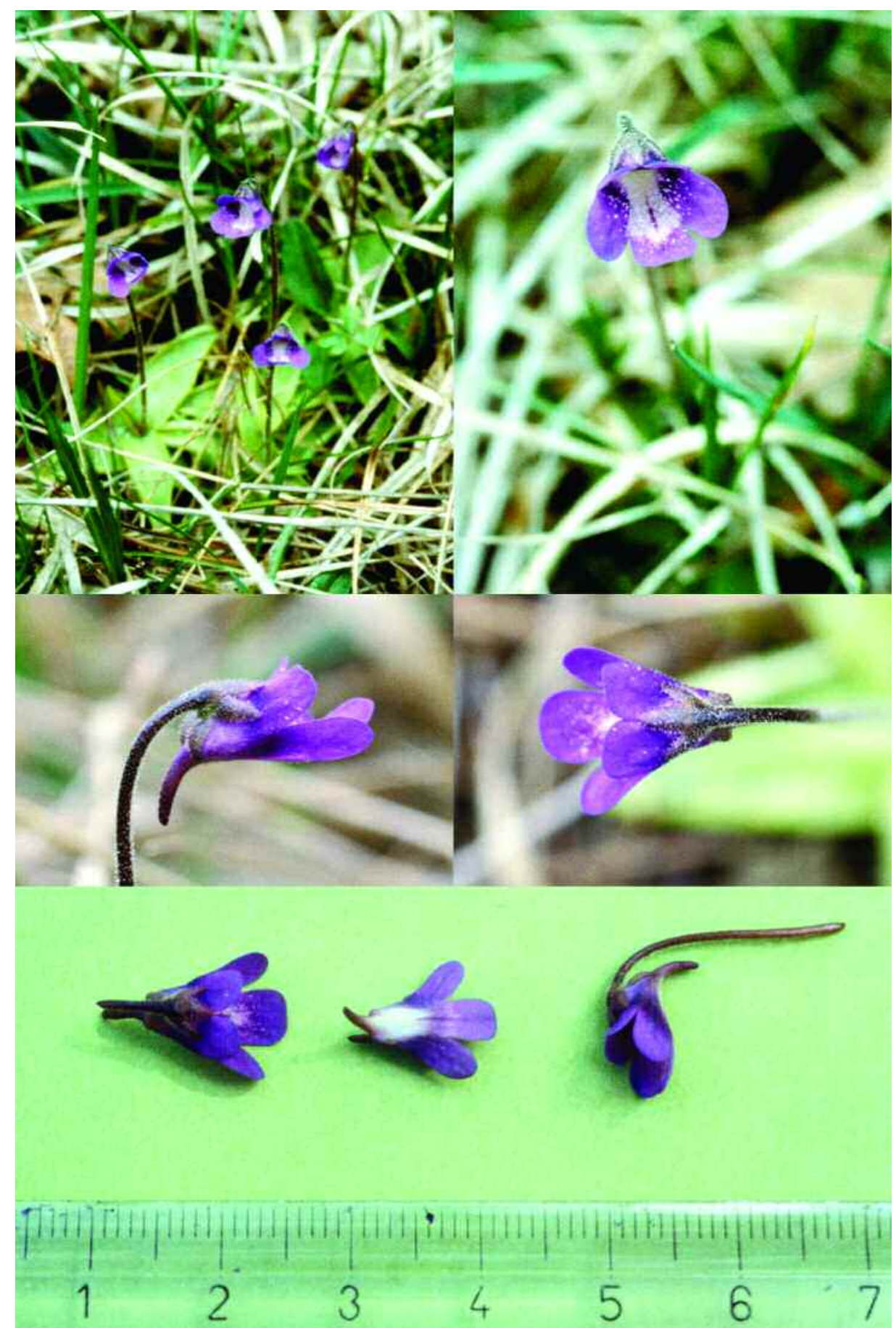

Figure 2: Morphology of the rosettes and flowers of $P$. vulgaris from Champagne state. Top two rows, plants in habitat; bottom row of flowers from cultivated specimens, flowers arranged according to Steiger (1978). Scale bar in centimeters. Photographs by Laurent Legendre. 
were, however, smaller than the ones of all the non-Champagne specimens (Student's t-test, $\mathrm{p}<0.01$ less than $1 \%$ ) except the smallest non-Champagne populations (Iceland, Slovenia; $0.2<\mathrm{p}<0.3$ ). As far as we know, the P. vulgaris plants from Iceland and Slovenia are the smallest in the species.

Calyx and corolla sizes were found to be comparable among all of the $P$. vulgaris plants in the study (Table 1). Lower calyx lobes were fused together for two thirds of their length for all the plants studied. Hibernacula were also similar in size and shape. The outer bud scales covered the entire bud and the buds did not bury themselves under the ground. Each year, the buds of the Champagne plants generated very large quantities of daughter buds (20-28 per mother bud on average) in contrast to all of the other $P$. vulgaris specimens which only produced a maximum of 1 daughter bud per year and most often none (Table 1). Mature seed capsules of the Champagne plants were perfectly round while the ones of the non-Champagne plants were pearshaped (Table 1; Figure 3).

During our growing experiments, the plants of the Champagne state were the last to break dormancy in the spring, and the last to go to rest in the fall. Their winter buds broke dormancy at least three weeks after the others so they were generating their first leaves when plants from the other sites were already flowering. They did not return to dormancy during the hot summer months like the other $P$. vulgaris specimens, which did so by the end of August. In contrast, they continued producing new leaves all the way through the end of October. More leaves were produced in the fall than in the spring so that seedlings of the Champagne plants often yielded blooming plants one year after being sown, unlike those of the non-Champagne plants which required 2-3 years to bloom. While conducting a similar growth trial on the western side of Paris, E. Partrat was unable to confirm the observed retardation in bud sprouting in the spring (personal communication).

All of the specimens living close to Rheims produced very large quantities of seeds (about 50 per seed capsule), out of which more than $95 \%$ were viable. Two years in a row, P. mundi flowers were pollinated with the pollen of either an Iceland or a Rheims $P$. vulgaris population ( 5 crosses per parent combination). The first cross always yielded about 80 seeds per capsule

\begin{tabular}{|c|c|c|c|c|c|c|c|}
\hline Location & $\begin{array}{l}\text { Rosette } \\
\text { diameter } \\
(\mathrm{cm})\end{array}$ & $\begin{array}{c}\text { Flowers } \\
\text { per year }^{\mathrm{a}}\end{array}$ & $\begin{array}{l}\text { Gemmae } \\
\text { per year }^{\mathrm{a}}\end{array}$ & $\begin{array}{c}\text { Capsule } \\
\text { shape }\end{array}$ & $\begin{array}{l}\text { Calyx } \\
\text { diamter } \\
(\mathrm{mm})\end{array}$ & $\begin{array}{l}\text { Corolla } \\
\text { width } \\
(\mathrm{mm})\end{array}$ & $\begin{array}{l}\text { Corolla } \\
\text { length } \\
(\mathrm{mm})\end{array}$ \\
\hline Chenay ${ }^{b}$ & $5.2 \pm 0.7$ & 2 & 20 & Round & $5.6 \pm 0.7$ & $10 \pm 1.9$ & $16 \pm 1.6$ \\
\hline Neuf-ans $b$ & $5.3 \pm 1.7$ & 2 & 22 & Round & $6.1 \pm 0.9$ & $11 \pm 1.4$ & $16 \pm 1.5$ \\
\hline Berru $^{b}$ & $6.3 \pm 1.6$ & 2 & 28 & Round & $6.6 \pm 0.7$ & $14 \pm 1.5$ & $17 \pm 0.6$ \\
\hline USA (Michigan) $^{\mathrm{c}}$ & $9.3 \pm 2.1$ & 6 & 0 & Pear-shaped & $6.6 \pm 0.8$ & $15 \pm 1.3$ & $18 \pm 1.0$ \\
\hline Iceland $^{\mathrm{c}}$ & $7.2 \pm 1.9$ & 4 & 0 & Pear-shaped & $6.1 \pm 0.7$ & $11 \pm 1.1$ & $16 \pm 1.1$ \\
\hline Slovenia $^{\mathrm{c}}$ & $7.5 \pm 1.8$ & 5 & 1 & Pear-shaped & $7.1 \pm 0.8$ & $11 \pm 1.0$ & $17 \pm 1.3$ \\
\hline France (vosges) ${ }^{\mathrm{c}}$ & $\begin{array}{l}11.2 \\
\pm 1.6\end{array}$ & 5 & 1 & Pear-shaped & $6.2 \pm 0.7$ & $11 \pm 1.3$ & $16 \pm 1.5$ \\
\hline France (jura) ${ }^{\mathrm{c}}$ & $10.9 \pm 2.3$ & 6 & 1 & Pear-shaped & $6.2 \pm 0.6$ & $11 \pm 1.1$ & $16 \pm 1.6$ \\
\hline France $(\text { alps })^{\mathrm{c}}$ & $15.1 \pm 1.2$ & 10 & 0 & Pear-shaped & $9.0 \pm 0.8$ & $11 \pm 1.8$ & $18 \pm 1.6$ \\
\hline \multicolumn{8}{|c|}{$\begin{array}{l}\text { a Maximum number typically observed. } \\
\mathrm{b}_{\text {Measurements taken on wild plants; similar figures were obtained on cultivated plants. }} \\
{ }^{\mathrm{c}} \text { Measurements taken on cultivated plants. }\end{array}$} \\
\hline \multicolumn{8}{|c|}{$\begin{array}{l}\text { Table 1: Morphological characteristics of various population of } P \text {. vulgaris. Values shown } \\
\text { with one standard deviation uncertainty when appropriate. Samplings contained five plants } \\
\text { and or flowers except for Chenay ( } 10 \text { plants), Neuf-ans ( } 19 \text { plants) and Berru ( } 3 \text { plants). }\end{array}$} \\
\hline
\end{tabular}



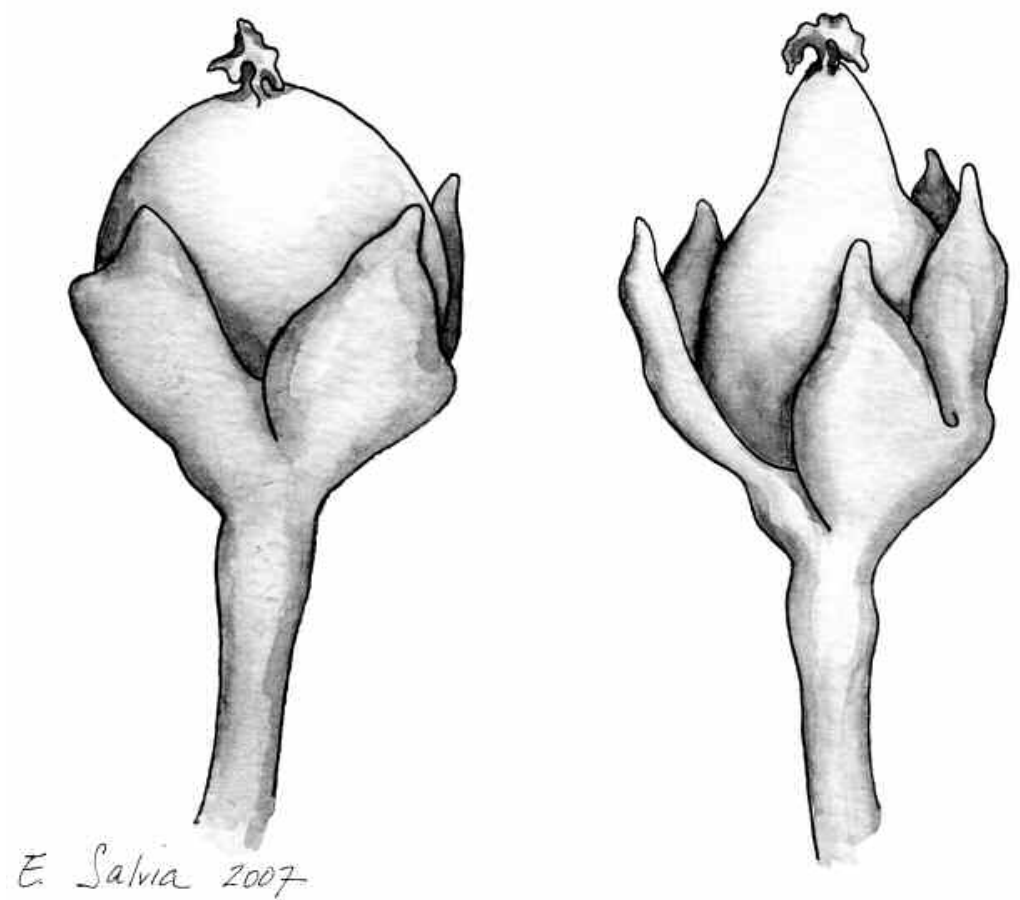

Figure 3: Seed capsules of $P$. vulgaris: from Champagne state near Berru (left), from the Alps (right). Drawn by Elizabeth Salvia.
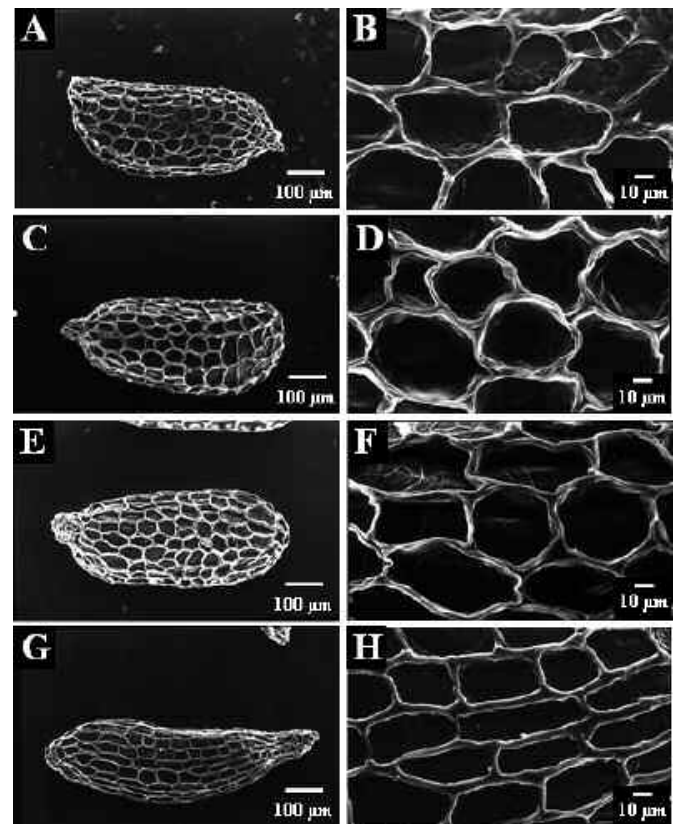

Figure 4: Scanning electron microscope view of seeds. A, B: Pinguicula vulgaris from Berru. C, D: Pinguicula vulgaris from the alps. E, F: Pinguicula vulgaris from Iceland. G, $\mathrm{H}$ : Pinguicula mundi. All seeds were obtained from cultivated plants. Photographs by Laurent Legendre. 
while the other never gave more than 5 seeds. Despite these numbers, all of the seeds that were generated yielded viable hybrid plantlets.

All of our attempts to evaluate the number of chromosomes of the Rheims plants failed because of the small size and round nature of $P$. vulgaris chromosomes. A maximum of 30 pairs of chromosomes was counted. This value is far below the expected $2 \mathrm{n}=64$ published for other $P$. vulgaris specimens (Casper 1966).

Scanning electron microscope analysis of Rheims $P$. vulgaris seeds and pollen are respectively shown in Figure 4 and 5. Seeds were ovoid and large with reticulate seed coats. Reticulations were square to round. They were similar to those of the alpine population and differed in elongation from those of $P$. mundi seeds. Pollen grains were round and shaped like pumpkins. They had a smooth to slightly rugose surface covered by large quantities of phenolic exudates. Anthers were unilocular and opened via a single lateral dehiscence hole to allow pollen grains release.

As previously noted by Casper (1966), the structure of the hairs at the entrance of the flower throat has some taxonomic value in Pinguicula. In the case of the Rheims plants, all hairs were resting upon a single epidermal cell and were linear (Figure 6). They were formed by a succession of approximately three elongated cells, the length and pigmentation of which reduces by half for each successive cell with increasing distance from the epidermis, and approximately 6 to 10 white round cells, piled on top of each other like beads on a string (uniseriate). Occasionally, one of these round cells had a twin one next to it (biseriate).

A patient observation of the hundreds of $P$. vulgaris specimens present at the Paris and Lyon herbaria, coupled with past records of the French flora, allowed us to more precisely define the exact distribution of this species in France. Most sites had been herborized very regularly in the 18th and 19th century. Then, $P$. vulgaris vanished at many sites during the first half of the 20th century (Figure 7). The Rheims populations all grow on the Champagne plateau, and are on the edge of what was once a large $P$. vulgaris population that covered the Paris valley. Most of the phenotypic diversity observed on herbarium specimens was found in the now-extinct Paris populations (very sad news indeed) and will be described in a separate article.

All three Champagne populations grew in alkaline bogs. These are characterised by massive growth of a vegetation (mostly grasses) that is surprisingly luxuriant for a temperate zone. Accumulation of dead plant debris is faster than its degradation so that peat matter accumulates. Since Sphagnum does not occur at such sites, the peat in alkaline bogs is different from the one found in acidic peat bogs (where Drosera grows in the northern hemisphere for example). Its mineralisation is also different since acidic peat bogs have soft waters and alkaline bogs hard waters. In the horticultural trades, acidic peat is often sold under the name blond or sphagnum peat while alkaline bogs peat is sold under the name black peat.

The smallest of the three Champagne populations (at Chenay) occurred in a very wet alkaline bog. Grasses were tall and grew in patches that formed little islands above shallow standing water. Plants developed with their roots in the water, growing through the dead and submerged leaves of grasses that were coated with hard mineral deposits. At the other two sites (Neuf Ans and Berru), the plants grew at the edge of a spring (in a horse field and on a trail grazed by horses respectively). The plants at Berru were living on a soil layer dating from the inferior Ypresian ("Sparnacian") from the tertiary period. The plants at Neuf Ans were growing on material dating from the middle Thanetian (tertiary period) that had spilled over an earlier geological formation (white chalk) from Senonian of the secondary period. This site was emerging from under a sandy soil layer of the superior Thanetian. Thus, in both cases, plants were found at a place where several soil ingredients (sand, clay and tuff or chalk) were mixed. The $\mathrm{pH}$ of all three sites near the plants was around 6.5. In this transitional ecotone between forested habitat on the sandy soil, and tall grass in the wetter part of the alkaline bog, competing vegetation was scarce. Water springs appeared at these spots after water had percolated through the forest soil and drained on the clay layer beneath it. It then accumulated to form a wetland (alkaline bog) lower down as depicted in Figure 8.

Most, if not all, insect captures were made at night or very early morning in all three 

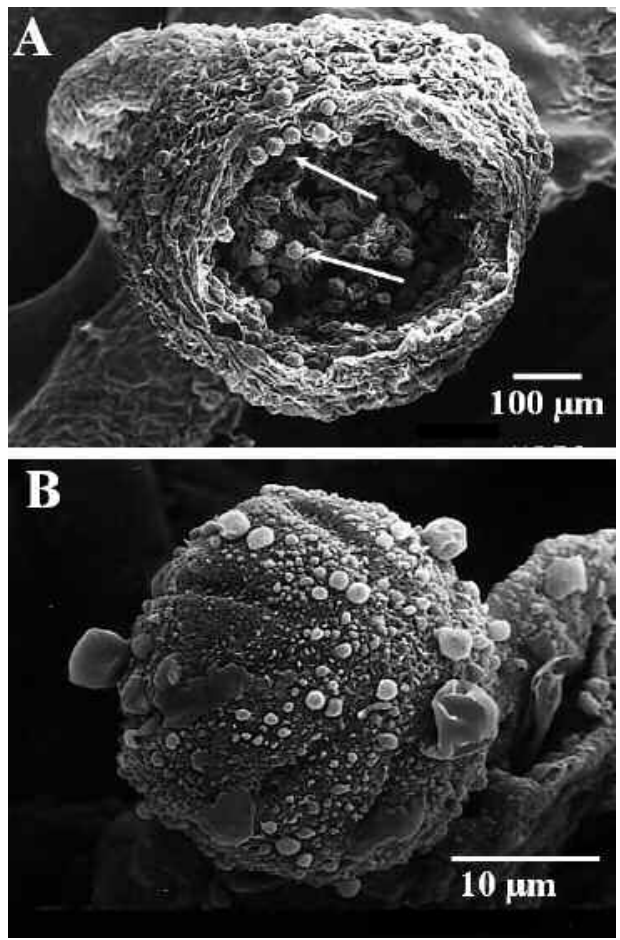

Figure 5: Scanning electron microscope view of anther and pollen. A: Pinguicula vulgaris anther for a plant from Chenay. Arrows indicate individual pollen grains. B: Pinguicula vulgaris pollen grain for a plant from Chenay. The bag-like structures on the pollen grains are phenolic secretions that have not been washed off during sample preparation. Photographs by Laurent Legendre.

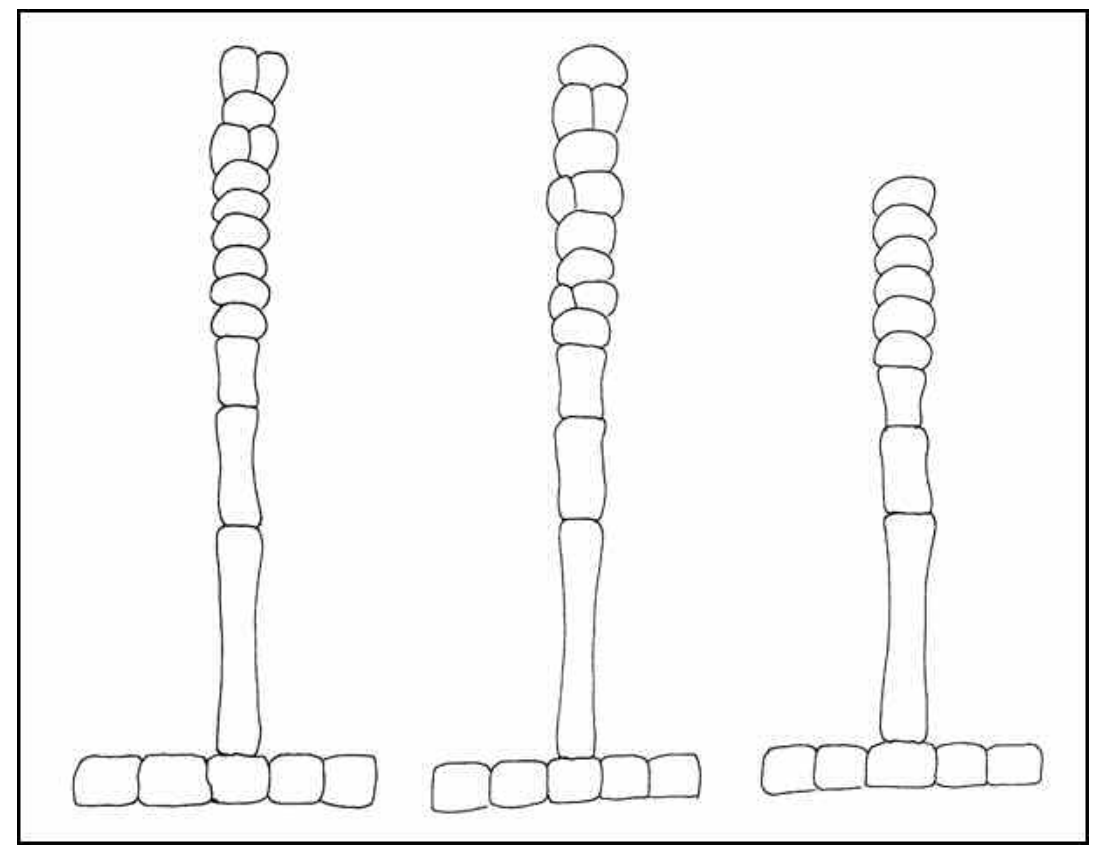

Figure 6: Three examples of flower throat hairs of $P$. vulgaris from Berru. Drawn by Laurent Legendre. 


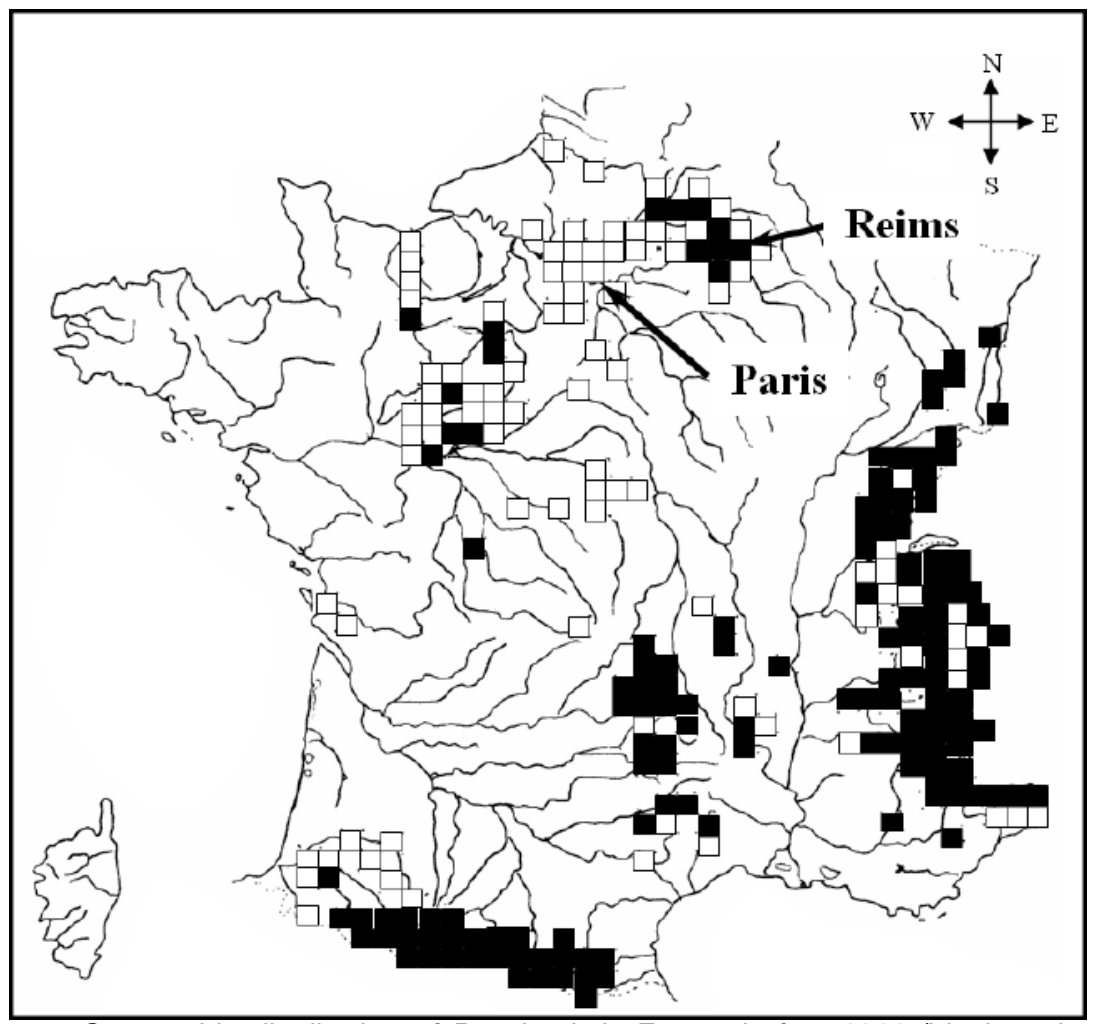

Figure 7: Geographic distribution of $P$. vulgaris in France before 1960 (black and white squares) and after 1960 (black squares only). Map prepared by Laurent Legendre according to Dupont, 1990.

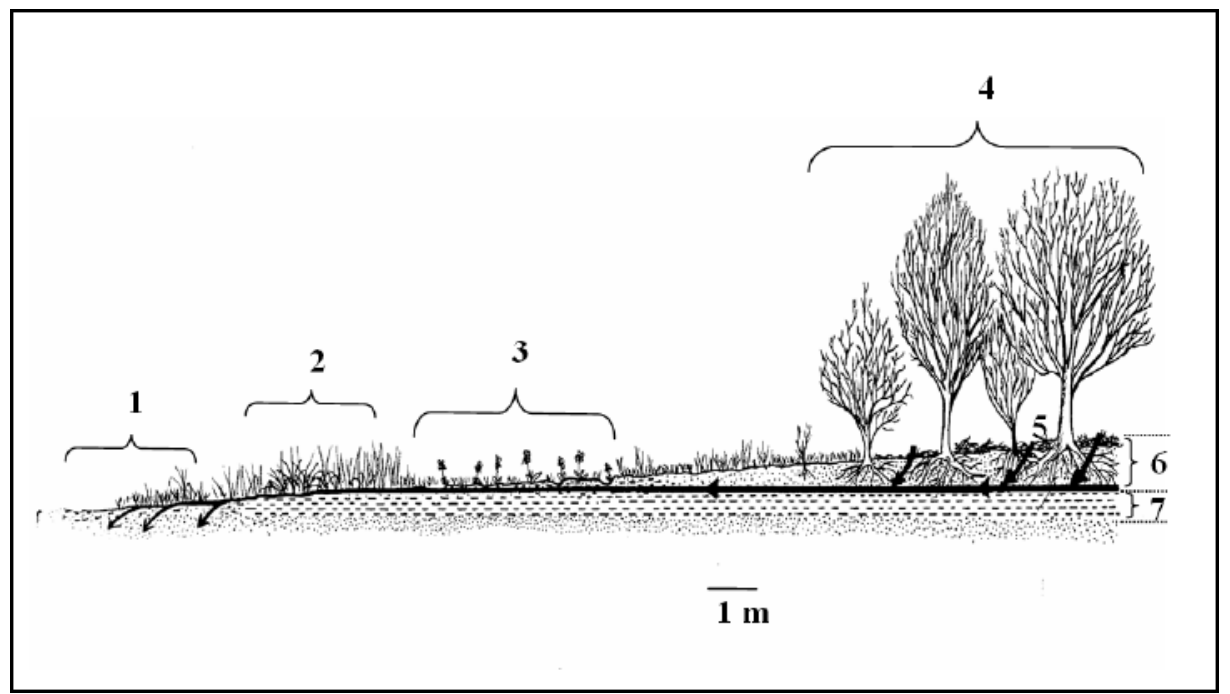

Figure 8: Biotic and abiotic conditions found In all P. vulgaris sites of this study. Local geological formations are made of alternate layers of sand (6) and clay (7) which are both calcareous. Rainwater in the forest (4) drains through the sandy soil (5) to collect on the clay layer and create a wetland (2) lower down the hill. The wetland drains in a lower sandy layer (1) and Pinguicula plants are found where the water first emerges and the sand and clay layers mingle (3). Drawn by Thomas Cieslack.

Volume 36 December 2007 
Champagne populations. Plant rosettes were the largest in very shaded spots but these plants produced the fewest (if any) flowers. Few insects could be seen on their leaves. Plants found in sunny spots were very small and generally generated only one flower per season. Their leaves were dry and free of sticky mucilage. Plants in intermediate areas (receiving no direct sun but lots of light) did best in terms of insect captures and flower production (often two per plant). Their rosette size was also close to that of the largest specimens.

The three populations decreased in size significantly during the years of this study (Table 2). At the Berru site, this could be attributed at least in part to the fact that outflow from a small artificial lake $3 \mathrm{~km}$ upstream had been diverted in late 1994, thus leading to a reduction in the quantity of water coming out of the spring where the plants were growing. Otherwise there was no obvious explanation (such as direct destruction of habitat) for the population decreases observed.

\begin{tabular}{|l|l|l|l|l|l|l|}
\hline \multicolumn{7}{|c|}{ Pinguicula vulgaris population estimates } \\
\hline & 1994 & 1995 & 1996 & 1997 & 1998 & 1999 \\
\hline Chenay & 200 & 150 & 50 & 20 & 10 & 10 \\
\hline Neuf-ans & 10,000 & 10,000 & 8,000 & 6,000 & 4,000 & 2,000 \\
\hline Berru & 2,000 & 1,500 & 500 & 200 & 100 & 100 \\
\hline $\begin{array}{l}\text { Table 2: Number of plants growing on each of the three Champagne } P \text {. vulgaris populations } \\
\text { from 1994 to 1999. }\end{array}$ \\
\hline
\end{tabular}

Discussion

The flowers of the $P$. vulgaris populations growing near the city of Rheims were similar in size and shape to those of other $P$. vulgaris populations. Pollen, seed, calyx and flower throat hair shapes and sizes were also similar to descriptions of other P. vulgaris specimens (Casper 1966; Steiger 1998). Differences were evident in the shape of the seed capsule, the rosette diameter, the number of flowers per season and the number of vegetative reproductive buds in the winter. Even though tedious, a study of all $P$. vulgaris populations worldwide would be necessary to appreciate the importance of such phenotypic variations in the natural variability of this genus.

Of all of the characters under study, the size of the rosette was the most variable one, with values ranging from 3.9 to $16.8 \mathrm{~cm}$ in diameter. Even though the Rheims plants were found to be the smallest of the group, it is difficult to draw any conclusion from this parameter because rosette size proved dependent upon the growing conditions (humidity, fertilization) unlike the size of the corolla and calyx. Moreover, the Rheims plants were not significantly different in size to some of the populations under study (i.e. those in Iceland and Slovenia).

Temperate Pinguicula in section Pinguicula (c.a. 15 species-see Casper 1966; Legendre 2000 for a sub-classification of the genus) differ from other species by their ability to generate a large number of vegetative reproductive buds from their winter hibernacula. Pinguicula vulgaris is an exception in this group (as confirmed by our measurements) because it typically produces very few vegetative buds. In this trait, the Rheims populations resemble the other species of section Pinguicula, such as $P$. grandiflora for example. By the same token, the globose shape of the seed capsule of the Champagne plants differs from the pear-shaped seed capsules of other $P$. vulgaris plants (this feature is also noted in Steiger 1970, 1973) and some members of section Pinguicula such as $P$. grandiflora. Globose seed capsules are produced by other members of this sub-section such as $P$. bohemica and $P$. leptoceras and by most other Pinguicula species (Casper 1966; Steiger 1970, 1973).

By generating more vegetative buds and less seeds (less flowers per plant per season), the Rheims plants differ in reproductive habit from the other $P$. vulgaris specimens under study. It is difficult to see whether this difference is linked to some local selection pressure element or is a mutation without evolutionary value. Nevertheless, it has the potential to affect the ratio of vegetative vs. sexual reproduction in these plants and therefore the flow of genetic information through their populations. Gemmae could participate in plant dispersion in the Champagne state since we have observed them in mud clods attached to the feet of horses crossing these populations.

The differences of timing in the growing phases that we observed on the Rheims plants are puzzling. These differences were significant and reproducible when comparative cultivation experiments 
were conducted in Rheims, but could not be seen when these same experiments were conducted just $200 \mathrm{~km}$ westward in a western suburb of Paris - this discrepancy may be due to differences in local weather conditions. Rheims is located on top of the Champagne plateau ( $86 \mathrm{~m}$ above sea level) and is subject to a continental climate with large and unpredictable temperature fluctuations, unlike the climate of Paris, which is buffered by the Atlantic Ocean and the human activity in its midst. The peculiar growing cycle of the Rheims plants, if real, may result in a competitive advantage by increasing annual growth, as was observed in P. longifolia subsp. longifolia (Garcia et al. 1994).

Pinguicula vulgaris was very common in the Champagne state more than 100 years ago. The drainage of the many wetlands has lead most populations to disappear. Within the remaining wetlands, it is hypothesized that $P$. vulgaris has disappeared, or is losing members, because of a lack of grazing (traditionally conducted by Polish horses) and the consequent overgrowth of grasses (very tall in these alkaline bogs). It is not clear why populations are diminishing in higher, more solid ground. The populations are blooming, do not show diseased plants, and their direct habitat is not undergoing any obvious land-use changes. We hypothesize that their disappearance is linked to macro-climatic changes that lead gradually to a lowering of the air humidity. High humidity and light were found to be required for optimum plant growth, blooming and insect capture in habitat. This part of France was renowned for its frequent foggy days and large wetlands (recorded in World War I and during the Napoleonic era). Now that the wetlands are dry for the most part (after peat extraction and water drainage) and that most of the forest has been cut down, one can observe a loss of air moisture, an increase in ground-level wind velocity that both lead to fewer foggy days (15 from the start of April to the end of August 1997). If such hypotheses are correct, it will be difficult to revert the course of extinction of these plants.

In a misguided effort to protect these plants, local carnivorous plant enthusiasts cut down most of the tree branches and removed grass at the Berru site in 2000. This led to a near-complete extinction of this population (down to less than 5 individuals a year later) and increased sun and wind exposure. The Pinguicula population has since grown back as the habitat recovered. Such measures have, nevertheless, benefited the native sundews (Drosera anglica). We suggest that the best results for Pinguicula protection will be achieved if the correct balance is reached between enough neighboring plant growth to raise the humidity and not too much overgrowth to let the plants access enough light. Diverting more water to their sites would also help along with regular grass cutting (like grazing by horses). When the populations of Pinguicula in Champagne state were larger, they were more resilient to minor changes in local abiotic conditions. Now, the few populations are in a much more precarious state.

Acknowledgements

The authors wish to acknowledge Dr C. Clement for his help during the scanning electron microscope studies, P. Lister for proof-reading this manuscript and Pr J.F. Steiger and E. Partrat for helpful discussions.

References:

Casper, S.J. 1966. Monographie der Gattung Pinguicula L. Bibliotheca Botanica 127/128. Stuttgart.

Dupont, P. 1990. Atlas partiel de la flore de France. Paris.

Garcia, M.B., Antor, R.J., and Villar, L. 1994. Phenomorphology and reproductive biology of Pinguicula longifolia Ramond ex DC. subsp. longifolia (Lentibulariaceae), a carnivorous endemic plant of the pyrenees. Acta Botanica Gallica. 141: 343-349.

Legendre, L. 2000. The genus Pinguicula L. (Lentibulariaceae): an overview. Acta Botanica Gallica 147: 77-95.

Steiger, J.F. 1970. Die underscheidung der schweizerischen Pinguicula arten; Beitrage zur kartierung der schweizer flora. Bern, 3: 1-8.

Steiger, J.F. 1973. Kapitel Pinguicula in: Hess H. et al., Flora der Schweiz, Bd. 3. Verlag Birkhauser Basel/Stuttgart, 260-264.

Steiger, J.F. 1978. Standardized photography of Pinguicula blossoms. Carniv. Pl. Newslett. 7: 43-50.

Steiger, J.F. 1998. Pinguicula (Lentibulariaceae): the cool climate species of the northern hemisphere-morphology, biology, cultivation. Second conference of the International Carnivorous Plant Society, Bonn. 